\title{
Planktonic metabolism in a Mediterranean reservoir during a near-surface cyanobacterial bloom
}

\author{
Enrique Moreno-Ostos ${ }^{1, *}$, Roberto L. Palomino-Torres ${ }^{1}$, C. Escot ${ }^{2}$ and J. $\mathrm{M}^{\mathrm{a}}$ Blanco $^{1}$ \\ ${ }^{1}$ Universidad de Málaga. Facultad de Ciencias. Departamento de Ecología. Grupo de Ecología Marina y \\ Limnología. Campus Universitario de Teatinos s/n. 29071. Málaga (Spain). \\ ${ }^{2}$ Empresa Metropolitana de Abastecimiento y Saneamiento de Aguas de Sevilla, S.A. EMASESA. C/ Escuelas \\ Pías 1. 41003. Sevilla (Spain). \\ * Corresponding author: quique@uma.es
}

Received: 04/05/2015 Accepted: 02/09/2015

\begin{abstract}
Planktonic metabolism in a Mediterranean reservoir during a near-surface cyanobacterial bloom

Summer blooms of large, filamentous, nitrogen-fixing and potentially toxic cyanobacteria are characteristic of many productive, warm monomictic reservoirs in the Mediterranean region, where they constitute stable assemblages. The accumulation of positively buoyant cyanobacteria at the surface layers of the water column favours - among others - the interception of light, inorganic carbon and nitrogen fluxes from the atmosphere, giving these prokaryotes a competitive advantage over other phytoplankton groups. Cyanobacterial blooms can cause deleterious effects to water quality and reservoir ecosystem services. Although the structure of the plankton community in reservoirs during cyanobacterial blooms is a well-known limnological issue, few studies have been undertaken on its functional characteristics. In this study, we used a high-resolution autonomous monitoring system to investigate the short-term changes in gross primary production (GPP), net ecosystem production (NEP) and community respiration $(\mathrm{R})$ in the near-surface waters of a Mediterranean reservoir during a dense summer cyanobacterial bloom. Our results demonstrate that during the bloom, the surface waters of the reservoir showed a well-balanced planktonic metabolism, with a mean GPP:R ratio not significantly different than 1 and therefore close positive correlations between GPP and R. Additionally, we found a positive correlation between the daily integrated incident light and the NEP:GPP ratio, while the mixed-layer depth and NEP:GPP ratio were negatively correlated, suggesting a central role for physical processes in the control of community metabolism and the persistence of the cyanobacterial bloom. The implications for the bloom stability and relevance for reservoir water quality management are noted.
\end{abstract}

Key words: Planktonic metabolism, gross primary production, net ecosystem production, community respiration, cyanobacterial bloom, high frequency reservoir monitoring, El Gergal reservoir.

\section{RESUMEN}

Metabolismo planctónico en un embalse mediterráneo durante el desarrollo de una proliferación de cianobacterias en superficie

Las proliferaciones masivas (blooms) estivales de cianobacterias filamentosas de gran tamaño, fijadoras de nitrógeno y potencialmente productoras de toxinas constituyen episodios frecuentes y estables en numerosos embalses productivos de régimen monomíctico cálido en la región Mediterránea. La acumulación de cianobacterias con flotabilidad positiva en las capas superficiales de la columna de agua favorece -entre otros factores- la interceptación de los flujos de luz, carbono inorgánico y nitrógeno molecular desde la atmósfera, lo que proporciona a estos procariotas una ventaja competitiva frente a otros grupos de organismos fitoplanctónicos. Los blooms de cianobacterias pueden inducir, además, efectos negativos sobre la calidad del agua y los servicios ecosistémicos de los embalses. Aunque es bien conocida la estructura de la comunidad planctónica en los embalses durante episodios de bloom de cianobacterias, hay pocos estudios sobre sus características funcionales. En este artículo usamos un sistema de monitoreo automático de alta resolución para investigar los cambios de pequeña escala temporal en la producción primaria bruta (GPP), producción ecosistémica neta (NEP) y respiración de la comunidad $(R)$ en las aguas superficiales de un embalse mediterráneo durante un intenso bloom estival de cianobacterias. Nuestros resultados demuestran que durante la ocurrencia del bloom las capas superficiales del embalse presentaron un 
metabolismo planctónico bien equilibrado, con valores medios de la razón GPP:R no significativamente diferentes a 1 e intensa correlación positiva entre GPP y $R$. Además, encontramos relación directa entre la radiación incidente diaria y la razón NEP:GPP, mientras que la profundidad de la capa de mezcla y la razón NEP:GPP se correlacionaron negativamente, lo que sugiere un papel clave de los procesos físicos en el control de las características metabólicas de la comunidad planctónica y en la persistencia del bloom. Se discuten implicaciones para la estabilidad del bloom y la relevancia de estos aspectos para la gestión de la calidad del agua embalsada.

Palabras clave: Metabolismo planctónico, producción primaria bruta, producción neta ecosistémica, respiración de la comunidad, bloom de cianobacterias, monitoreo de alta frecuencia en embalses, embalse de El Gergal.

\section{INTRODUCTION}

The metabolic status of planktonic communities in the surface waters of lakes and reservoirs is mainly driven by photosynthetic primary production and aerobic respiration. Gross primary production (GPP) represents the gross fixation of inorganic carbon by photosynthesis. Community respiration $(\mathrm{R})$ is the mineralization of organic carbon to dissolved inorganic carbon and $\mathrm{CO}_{2}$, and net ecosystem production (NEP) is the difference between GPP and R (Cole et al., 2000). The balance between GPP and R, determined either as the GPP:R ratio or the NEP value, is a measure of the ecosystem's metabolism (Odum, 1956; Staehr \& Sand-Jensen, 2007) and defines the global role of aquatic ecosystems as sources or sinks of atmospheric $\mathrm{CO}_{2}$ (del Giorgio \& Duarte, 2002). When NEP is positive (NEP $>0$ ) and GPP is larger than $\mathrm{R}(\mathrm{GPP}: \mathrm{R}>1)$, ecosystems are termed net autotrophic. These kinds of systems can store and/or export organic carbon to adjacent ecosystems (Schindler et al., 1997) and constitute atmospheric carbon sinks. By contrast, net heterotrophic ecosystems are characterised by GPP:R $<1$ and NEP $<0$, which suggests that the system consumes more organic carbon than was produced by GPP within its boundaries. This implies that respiration within the ecosystem should be subsidised by allochthonous organic matter from the watershed (Cole et al., 2000). Net heterotrophic ecosystems behave as global $\mathrm{CO}_{2}$ sources for the atmosphere. Therefore, aquatic ecosystems are critical components of the metabolism of the biosphere and the associated $\mathrm{CO}_{2}$ exchange with the atmosphere (Duarte \& Prairie, 2005). Consequently, it is of paramount importance for studies of biogeochemical and global change to obtain an appropriate knowledge about the metabolism of lake and reservoir ecosystems. Such knowledge could also be very useful for guiding ecological modelling, active water quality policies and ecosystem management strategies (Hanson et al., 2006; Williamson et al., 2008, Staehr et al., 2010a).

The selection of appropriate monitoring and data analysis methodologies is critical to obtain reliable ecosystem metabolism information at the fundamental time scales operating in pelagic communities. Metabolic rates are typically measured in water samples collected from the lake and incubated in situ within bottles or chambers. Unfortunately, it is well known that the incubation of water samples in bottles has several caveats that make accurate estimations of pelagic metabolic rates difficult (Gerhart \& Likens, 1975; Bender et al., 1987; Petersen et al., 1997, 1999; Chen et al., 2000; Staehr et al., 2010a). Despite this, incubation techniques are still the most commonly applied method for studying aquatic ecosystem metabolism.

Interestingly, an alternative holistic wholelake methodology for estimating metabolic rates was proposed many years ago by the eminent ecologists H. T. and E. P. Odum (Odum \& Odum, 1955; Odum 1956, 1957; Odum \& Hoskins, 1958). This method requires tracking over a few days the relatively short-term (typically 1-3-hour intervals) changes in dissolved oxygen concentration measured directly within the aquatic ecosystem, and calculating an oxygen mass balance, taking into account that dissolved oxygen changes result from the budget between the phytoplankton GPP, community R and the 
physical exchange of oxygen with the atmosphere (Odum, 1956). Although this free-water method is based on an interesting ecosystem approach and provides whole-lake metabolic rates, traditionally it has been less popular than the various bottle incubation methods. One reason for this clearly resides in the huge time and effort required to obtain short-term dissolved oxygen data using the manual Winkler titration technique. However, the recent development of relatively low-cost, automatic and reliable oxygen probes has again strongly promoted the consideration and use of free-water methods as a powerful alternative for exploring lake metabolism at various time and spatial scales (Staehr et al., 2010a; Laas et al., 2012). Nevertheless, as with all ecological methodologies, some assumptions and uncertainties are embedded in the diel freewater oxygen technique. Some of these are related to the difficulty of quantifying the air-water flux, the missing anaerobic respiration processes, the spatial and temporal heterogeneity due to variable zones of influence on the oxygen probe, the assumption of the same respiration rates during the day and night, and the oxygen-to-carbon conversion problems (Staehr et al. 2010a).

Summer blooms of large, filamentous, nitrogen-fixing and potentially toxic cyanobacteria are characteristic of many productive, warm monomictic reservoirs in the Mediterranean region, where they constitute stable assemblages. Harmful cyanobacterial blooms can induce deleterious effects on stored water quality and many reservoir ecosystem services (Backer, 2002; Paerl $\&$ Otten, 2013), resulting in serious environmental, health and economic damage. This is an especially relevant feature of the Mediterranean semiarid region, where water is a scarce and endangered resource, and both water quantity and quality require wise and limnologically based management (Moreno-Ostos et al., 2008a). It is therefore important to acquire a profound knowledge about the structure and function of cyanobacterial blooms in reservoirs, both from a scientific and a water resource management perspective. Although the structure of the plank-

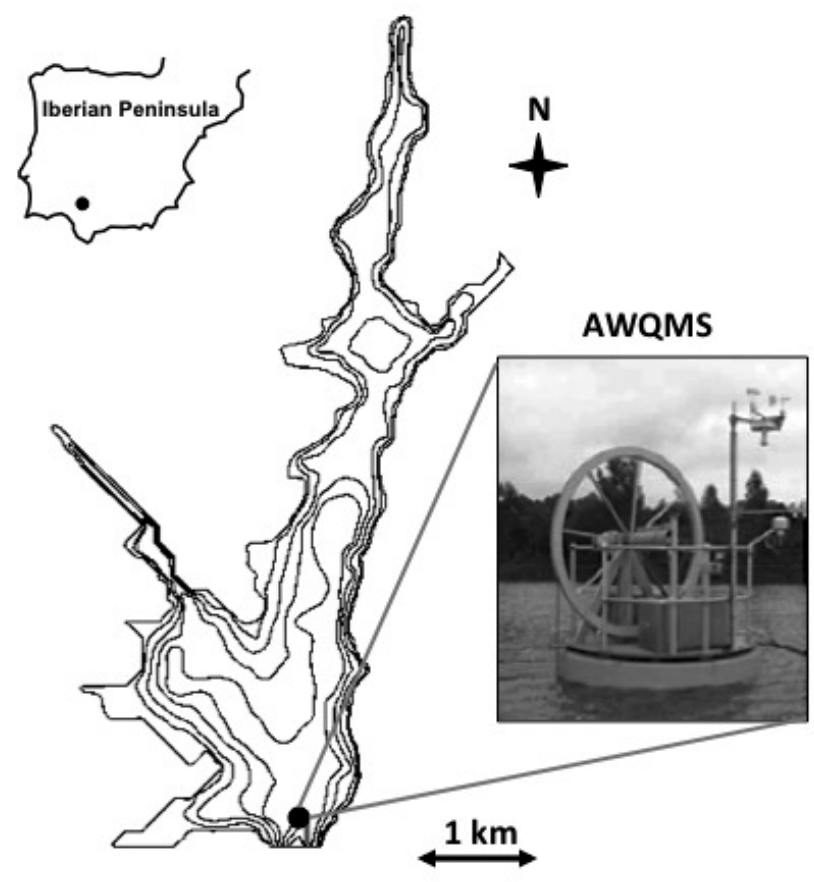

Figure 1. Location of the El Gergal reservoir on the Iberian Peninsula. Contour lines in the bathymetric map represent $5 \mathrm{~m}$ isobaths. The solid dot inside the reservoir shows the position of the AWQMS. Redrawn from Moreno-Ostos et al. (2009b). Localización del embalse de El Gergal en la Península Ibérica. Las líneas de contorno en el mapa batimétrico representan isóbatas cada 5 m. El punto en el embalse muestra la posición de la AWQMS. Redibujado de Moreno-Ostos et al. (2009b). 
ton community in Mediterranean reservoirs during cyanobacterial blooms is well-known, studies focusing on its metabolic and functional characteristics, essential for understanding energy and nutrient flows, are still lacking. The high phytoplankton biomass achieved during cyanobacterial blooms in lakes and reservoirs could significantly enhance primary production and could also promote intense microbial heterotrophic processes. In this paper, we explore plankton metabolism in the surface layers of a Mediterranean reservoir to ascertain if the development of large cyanobacterial summer blooms would promote net autotrophy, net heterotrophy, or an equilibrated and rather constant ecosystem metabolism. In addition, we hypothesize that physical factors (such as the mixed-layer depth, largely manageable in multiple-withdrawal reservoirs) could affect the cyanobacterial bloom metabolic rates. To achieve these objectives, we combined the diel oxygen free-water technique for aquatic ecosystem metabolism with an automatic high-frequency monitoring system to estimate the reservoir's physico-chemical features, primary production, community respiration and metabolic ratios at a fine scale during a dense summer cyanobacterial bloom.

\section{MATERIAL AND METHODS}

\section{Study site}

El Gergal is a medium size reservoir (surface area: $250 \mathrm{ha}$; volume: $35 \mathrm{hm}^{3}$; maximum depth: $37 \mathrm{~m}$; mean depth: $15.7 \mathrm{~m}$ ) located in the catchment of the Rivera de Huelva River, a tributary of the Guadalquivir River on the Atlantic coast of Andalucía (Southern Spain) (Fig. 1). It is part of a four-reservoir system, which supplies water to the city of Sevilla and its metropolitan area (ca. 1.3 million inhabitants). The thermal regime of the reservoir is warm monomictic (Moreno-Ostos et al., 2009a; 2009b) and the functional composition and seasonal succession of phytoplankton are strongly associated with the water-column thermal structure, turbulent mixing and hydraulic management strategies (Hoyer et al., 2009). Fur- ther information on the physical, chemical and biological features of the El Gergal reservoir can be found elsewhere (Cruz-Pizarro et al., 2005; Moreno-Ostos et al., 2007a; Moreno-Ostos et al., 2008a; Hoyer et al., 2009, Moreno-Ostos et al., 2009a; Moreno-Ostos et al., 2009b; Moreno Ostos et al., 2012).

\section{Automatic Water Quality Monitoring Station}

Hourly variations in the near-surface oxygen concentration, water temperature, and water salinity were recorded by an YSI 6920 multiparameter probe fitted to an Automatic Water Quality Monitoring Station (AWQMS, see Fig. 1), and the data were recorded at 2 metres depth. The AWQMS was also equipped with a self-contained thermistor chain (HOBO), which provided hourly data about the water-column thermal structure. The aerial part of the AWQMS was fitted with an array of meteorological instruments, including - among many others - a pyranometer, an anemometer and a barometer. Meteorological data were recorded every hour. The AWQMS was mounted on a platform buoy and moored near the deepest point in the reservoir's lacustrine zone (Fig. 1). All acquired data were stored in an industrial computer located within the AWQMS and remotely downloaded via Wi-Fi to the Seville Water Supply Company (EMASESA) databases and reservoir-monitoring interface systems. For this study, physico-chemical data were recorded during a 21-day period in August 2008 (August 9th and 12th-31st; during August 10th and 11th the multiparameter probe failed), which coincided with the occurrence of the highest cyanobacterial bloom recorded in the El Gergal reservoir that year.

More detailed descriptions of the El Gergal AWQMS and associated sensors are given in Rouen et al. (2005) and Escot et al. (2009).

\section{Chlorophyll a concentration, phytoplankton composition and biovolume}

Throughout the study period, hourly chlorophyll $a$ concentrations ( $\mathrm{Chl} a$ ) were measured by an autonomous in vivo fluorometer (Minitracka 
MKII) fitted to the AWQMS at a 2 metre depth because bloom-forming cyanobacteria in El Gergal are all positively buoyant organisms.

In addition, three surveys were made at the beginning (August 10th), middle (August 20th) and end (August 31st) of the study period to obtain water samples for phytoplankton composition and biovolume. Samples were collected at three discrete depths within the epilimnion (at the surface, 2 metre and 5 metre depths) using a $5 \mathrm{~L}$ Van Dorn sampler and were fixed in situ using Lugol's solution. Once in the laboratory, phytoplankton species were identified and counted using an inverted microscope following the Utermöhl method (1958). Morphological measurements were carried out with an inverted Leica DMIL microscope. Photomicrographs were taken with an Allied Pike F145C-IRF16 digital camera, and images were processed using free software developed at the University of Málaga by one of the authors (Fot-O-matón, J. M. Blanco). For every sample, several morphometric parameters were measured for at least 100 cells/colonies of each phytoplankton species. Cell volumes were calculated following Hillebrant et al. (1999).

Epilimnetic mean biovolume was obtained by adding up the weighted-average value between consecutive sampling depths, as

$$
\mathrm{BV}_{\text {epi }}=\left(\mathrm{BV}_{0}+2.5 \times \mathrm{BV}_{2}+1.5 \times \mathrm{BV}_{5}\right) / 5
$$

where $\mathrm{BV}_{\text {epi }}$ is the weighted-average biovolume in the epilimnion, and $\mathrm{BV}_{0}, \mathrm{BV}_{2}$ and $\mathrm{BV}_{5}$ are the measured biovolumes at 0,2 and 5 metre depths, respectively.

\section{The diel free-water oxygen technique for plankton metabolism}

Planktonic metabolic rates were estimated from hourly oxygen concentration data recorded by the AWQMS. NEP for hourly intervals was calculated according to the expression of Cole et al. (2000):

$$
\mathrm{NEP}_{\text {hour }}=\Delta \mathrm{O}_{2}-D / Z_{\text {mix }}
$$

where $\Delta \mathrm{O}_{2}$ is the change in oxygen concentration over one hour, $D$ is the diffusive exchange with the atmosphere during this period, and $Z_{\text {mix }}$ is the thermocline depth, which was inferred from the hourly temperature profiles (Staehr \& SandJensen, 2007). Atmospheric exchange was calculated as

$$
D=k\left(\mathrm{O}_{2}-\mathrm{O}_{2 \mathrm{sat}}\right)
$$

where $\mathrm{O}_{2}$ is the measured oxygen concentration, $\mathrm{O}_{2 \text { sat }}$ is the oxygen concentration in equilibrium with the atmosphere at the ambient temperature and measured salinity and corrected for barometric pressure, and $k$ is the piston velocity, a coefficient of oxygen exchange at a given temperature (Staehr et al., 2012). Piston velocity was computed for each temperature according to Jähne $e t$ al. (1987) as

$$
k=k_{600}(\mathrm{Sc} / 600)^{-0.5}
$$

where $k_{600}$ is $k$ for a Schmidt number $(\mathrm{Sc})$ of 600 and can be calculated as function of the wind speed following Cole \& Caraco (1998).

Biologically, NEP is a balance between the oxygen gains from photosynthesis and the oxygen depletion during respiration (Staehr et al., 2010a); consequently, it can acquire positive or negative values.

We calculated the daytime NEP ( $\left.\mathrm{NEP}_{\text {daytime }}\right)$ from the $\mathrm{NEP}_{\mathrm{hr}}$ values following Staehr et al. (2010a) as

$$
\begin{aligned}
\mathrm{NEP}_{\text {daytime }} & =\text { mean } \mathrm{NEP}_{\text {hr }} \text { during daylight } \times \\
& \times \text { daylight hours }
\end{aligned}
$$

Because no photosynthesis occurs at night, calculations of $\mathrm{NEP}_{\mathrm{hr}}$ during the night divided by the night length $(\mathrm{h})$ provided the hourly rate of ecosystem respiration $\left(\mathrm{R}_{\mathrm{hr}}\right)$. Assuming the same respiration rate during night and day (Hanson et al., 2006; Lauster et al., 2006; Staehr et al., 2010a), we obtained the daily respiration rate $\left(R_{\text {day }}\right)$ by multiplying the $R_{h r}$ by $24 \mathrm{~h}$. Respiration between sunrise and sunset $\left(R_{\text {daytime }}\right)$ is calculated from $\mathrm{R}_{\mathrm{hr}}$ extrapolated over the day length (Staehr et al., 2010a). 

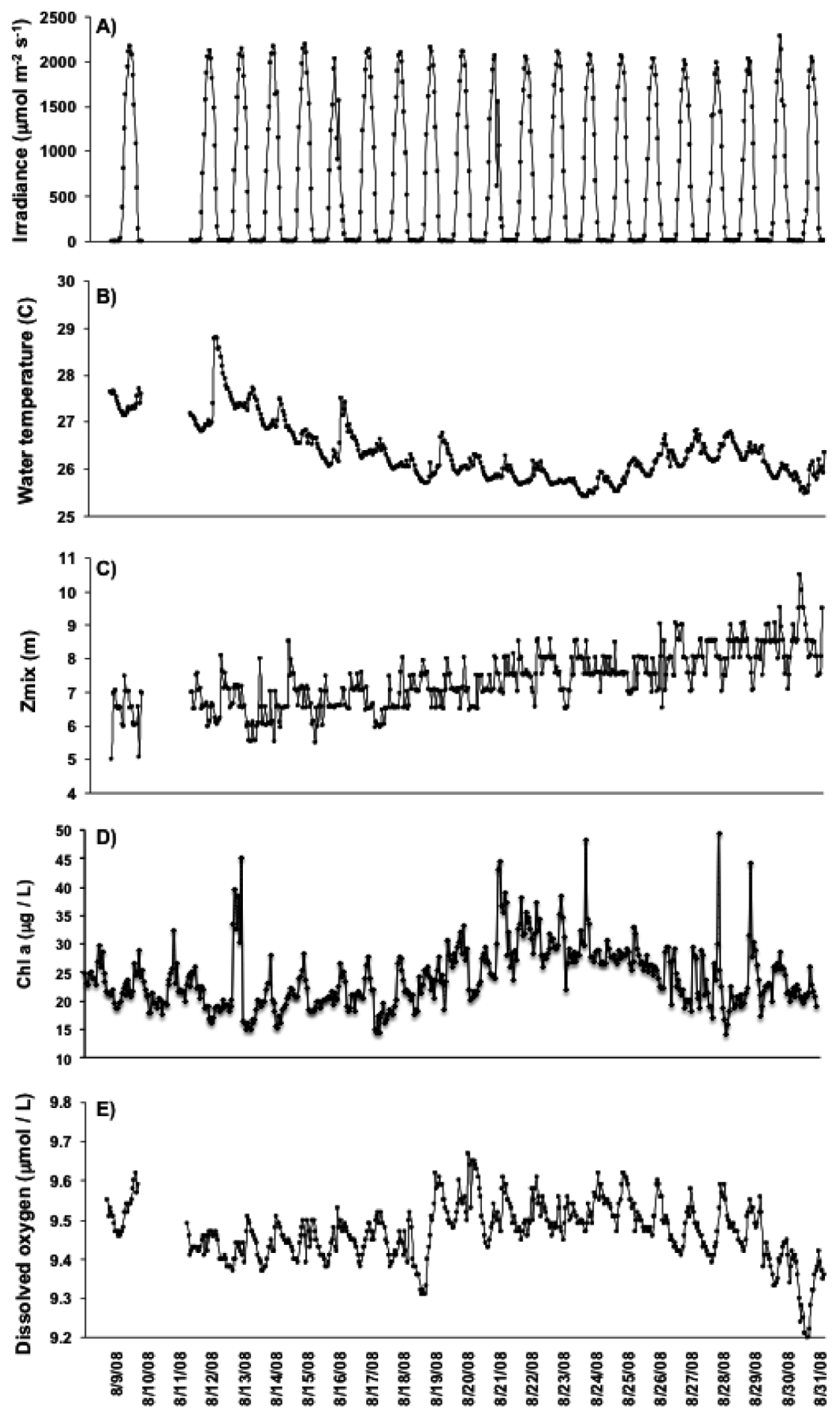

Figure 2. Hourly variations of A) surface PAR $\left.\left(\mu \mathrm{mol} \mathrm{m} \mathrm{m}^{-2} \mathrm{~s}^{-1}\right), \mathrm{B}\right)$ water temperature $\left.\left({ }^{\circ} \mathrm{C}\right), \mathrm{C}\right)$ mixed-layer depth $\left.\left(Z_{\mathrm{mix}}, \mathrm{m}\right), \mathrm{D}\right)$ Chlorophyll $a$ concentration $(\mu \mathrm{g} / \mathrm{L})$ and E) dissolved oxygen concentration $(\mu \mathrm{mol} / \mathrm{L})$ in the near-surface waters of El Gergal reservoir during the study period. Variaciones horarias de A) PAR en superficie ( $\left.\left.\mu \mathrm{mol} \mathrm{m} \mathrm{m}^{-2} \mathrm{~s}^{-1}\right), \mathrm{B}\right)$ temperatura del agua $\left({ }^{\circ} \mathrm{C}\right)$, C) profundidad de la capa de mezcla $\left.\left(\mathrm{Z}_{\text {mix }}, m\right), D\right)$ concentración de Clorofila a $(\mu g / L)$ y $\left.D\right)$ concentración de oxígeno disuelto $(\mu m o l / L)$ en las aguas superficiales de El Gergal durante el periodo de estudio. 
Gross primary production (GPP) was determined as

$$
\mathrm{GPP}=\mathrm{NEP}_{\text {daytime }}+R_{\text {daytime }},
$$

and finally, daily NEP ( $\left.\mathrm{NEP}_{\text {daily }}\right)$ was calculated as

$$
\mathrm{NEP}_{\text {daily }}=\mathrm{GPP}-R_{\text {day }}
$$

where respiration is expressed in positive numbers (Staehr et al., 2010a, 2012).

Chlorophyll-specific production rates were obtained by dividing the GPP between the corresponding mean daily $\mathrm{Chl} a$.

\section{Statistical analyses}

For analytical and comparison purposes, means \pm standard deviations were computed for the main limnological variables and the estimated metabolic rates and ratios.

Pearson linear correlation analysis was used to test the relationships between the variables. To determine if the correlation slopes were significantly different from 1 , Student's t-test ( $\alpha=0.05)$ was applied to the differences between the slopes divided by the difference of the standard errors of the slopes (see Zar, 1999).

\section{RESULTS}

\section{Physico-chemical variables}

Figure 2 shows the hourly variations in the physico-chemical variables considered for planktonic metabolism calculations. During the study period, the incident PAR flux depicted a marked and consistent diel pattern, with sunrise around 8:30 am, sunset around 9:30 pm and a photoperiod characterised by a 14:10-hour light-to-dark ratio. Maximum mean PAR values of $2076 \pm$ $63 \mu \mathrm{mol}$ photons $\mathrm{m}^{-2} \mathrm{~s}^{-1}$ were always recorded at 3:00 pm (Fig. 2A).

Near-surface water temperatures (Fig. 2B) remained high despite a clear decreasing trend with time. The mean surface water temperature was
$26.5 \pm 0.7^{\circ} \mathrm{C}$, with a minimum mean value of $26 \pm 0.5^{\circ} \mathrm{C}$ during the late night and a maximum mean value of $26.8 \pm 0.7^{\circ} \mathrm{C}$ in the afternoon.

The reservoir was thermally stratified throughout the study period, with a stable thermocline located at a $7.3 \pm 0.8 \mathrm{~m}$ depth. The mixed-layer depth moved progressively into deeper waters as a result of the thermocline erosion process, with a deepening rate of approximately $0.1 \mathrm{~m} / \mathrm{d}$ (Fig. 2C).

Dissolved oxygen concentration in the surface waters of El Gergal also showed a clear daily pattern (Fig. 2E). Daily mean minimum values of $237 \pm 2 \mu \mathrm{mol} / \mathrm{L}$ were measured at 10:00 am, with daily mean maximum values of $241 \pm 2 \mu \mathrm{mol} / \mathrm{L}$ typically recorded during the late evening around 9:00 pm.

\section{Chlorophyll a concentration, phytoplankton biovolume and community composition}

During the study period, near-surface Chl $a$ ranged between $14 \mu \mathrm{g} / \mathrm{L}$ and $49 \mu \mathrm{g} / \mathrm{L}$, with an overall mean of $24 \pm 5.4 \mu \mathrm{g} / \mathrm{L}$ (Fig. 2D).

Total phytoplankton biovolume in the epilimnetic waters of the El Gergal reservoir was very high (averaging $155 \times 10^{6} \mathrm{\mu m}^{3} / \mathrm{mL}$; maximum $286 \times 10^{6} \mu \mathrm{m}^{3} / \mathrm{mL}$; see Fig. 3 ). The phytoplank-

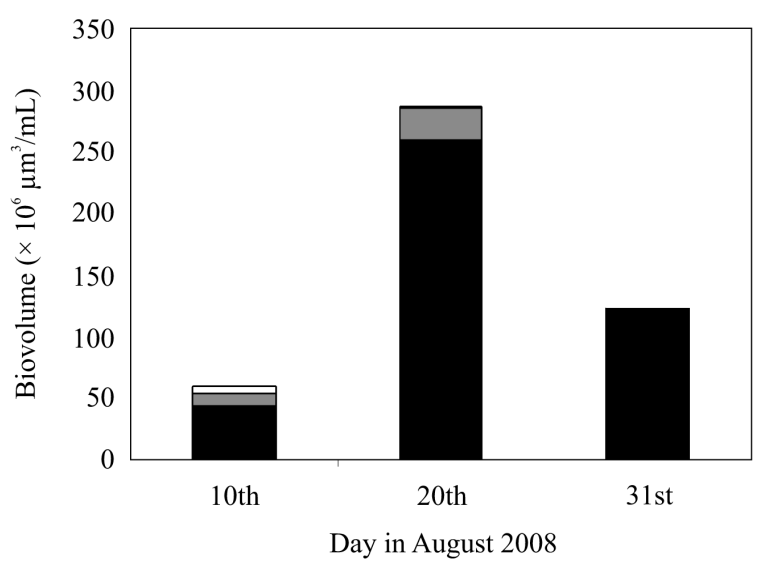

Figure 3. Phytoplankton epilimnetic biovolume during the study period and the contribution of cyanobacteria (black bar), dinoflagellates (grey bar) and other phytoplankters (white bar). Biovolumen fitoplanctónico en el epilimnion durante el periodo de estudio, así como la contribución de cianobacterias (barra negra), dinoflagelados (barra gris) y otros grupos fitoplanctónicos (barra blanca). 
ton community was strongly dominated by heterocystous filamentous cyanobacteria (Aphanizomenon flos-aquae and Anabaena planctonica). Cyanobacteria accounted for between $73 \%$ and $96 \%$ of the total phytoplankton biovolume, with an increasing presence throughout the study period. Dinoflagellates (Ceratium hirundinella) were the second phytoplankton group in terms of biovolume, representing between $4 \%$ and $20 \%$ of total phytoplankton biovolume. All remaining phytoplankton groups always represented less than $5 \%$ of the total epilimnetic photoautotrophic biovolume.

\section{Surface planktonic metabolism}

Figure 4A shows the diel changes in gross primary production (GPP), community respiration (R) and net ecosystem production (NEP) calculated for the near-surface layer of El Gergal. Phytoplankton gross primary production ranged between $2.64 \mu \mathrm{mol} \mathrm{O} \mathrm{O}^{-1} \mathrm{~d}^{-1}$ and $17.59 \mu \mathrm{mol} \mathrm{O}_{2}$ $\mathrm{L}^{-1} \mathrm{~d}^{-1}$, with an overall mean of $7.0 \pm 3.5 \mu \mathrm{mol}$ $\mathrm{O}_{2} \mathrm{~L}^{-1} \mathrm{~d}^{-1}$. Respiration rates $(\mathrm{R})$ ranged between $0.56 \mu \mathrm{mol} \mathrm{O}_{2} \mathrm{~L}^{-1} \mathrm{~d}^{-1}$ and $11.43 \mu \mathrm{mol} \mathrm{O} \mathrm{O}^{-1}$ $\mathrm{d}^{-1}$, with an overall mean of $5.9 \pm 2.6 \mu \mathrm{mol} \mathrm{O}$ $\mathrm{L}^{-1} \mathrm{~d}^{-1}$. NEP rates were positive during $85 \%$
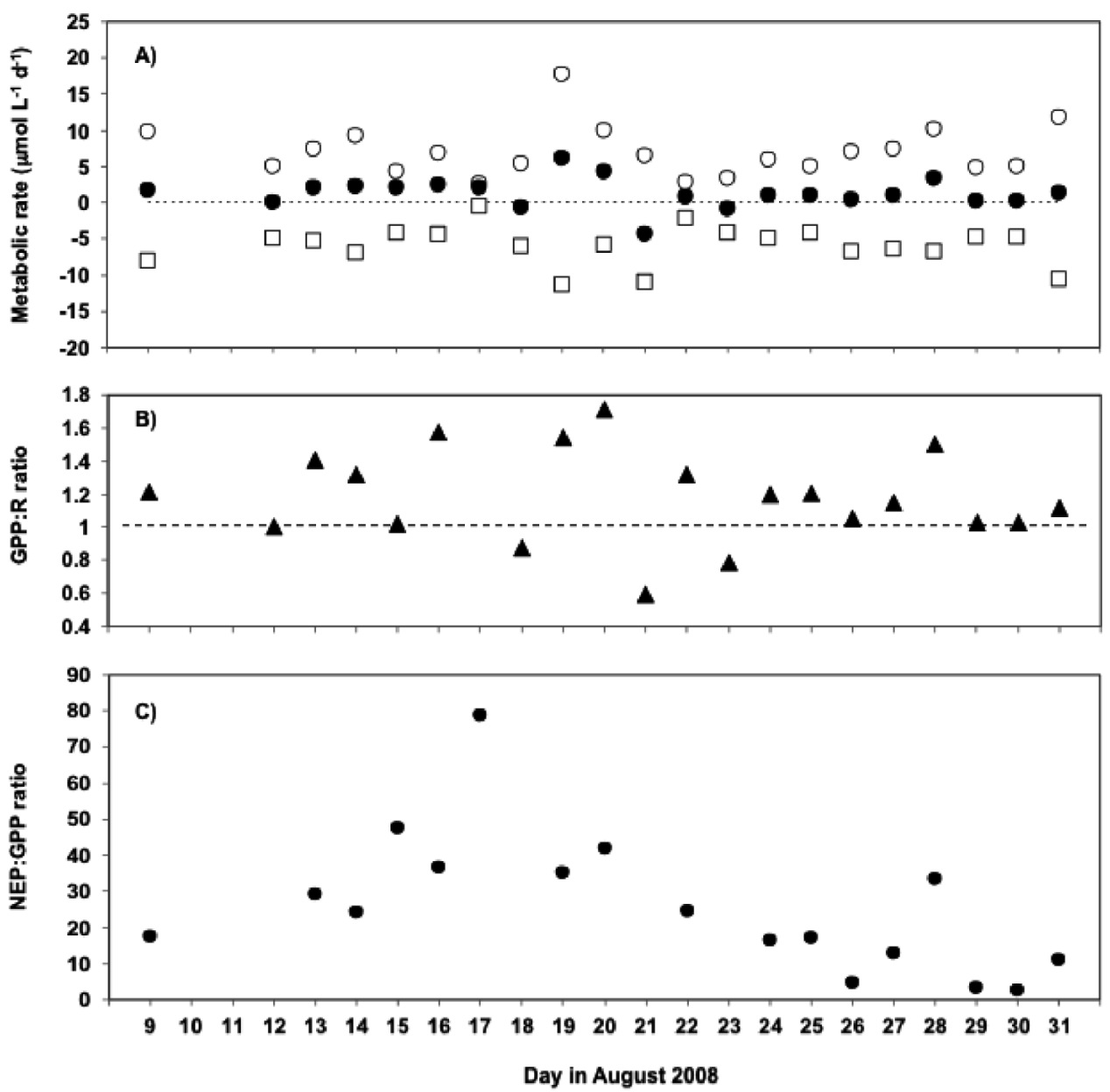

Figure 4. A) Daily values of gross primary production (GPP, open circles), net ecosystem production (NEP, black circles) and community respiration ( $\mathrm{R}$, open squares) in the near-surface waters of El Gergal reservoir. $\mathrm{R}$ is shown as negative numbers for plotting purposes. B) GPP:R ratio values. C) NEP:GPP ratio values. A) Valores diarios de producción primaria bruta (GPP, círculos blancos), producción ecosistémica neta (NEP, círculos negros) y respiración de la comunidad ( $R$, cuadrados blancos) en las aguas superficiales de El Gergal. $R$ se presenta con valores negativos por motivos de representación gráfica. B) Valores de la razón GPP:R. C) Valores de la razón NEP:GPP. 
of the study period. The NEP overall mean was $1.1 \pm 2.1 \mu \mathrm{mol} \mathrm{O} \mathrm{O}_{2} \mathrm{~L}^{-1} \mathrm{~d}^{-1}$ and ranged between $-4.47 \mu \mathrm{mol} \mathrm{O} \mathrm{L}^{-1} \mathrm{~d}^{-1}$ and $6.16 \mu \mathrm{mol} \mathrm{O} \mathrm{O}_{2} \mathrm{~L}^{-1} \mathrm{~d}^{-1}$.

The overall mean GPP:R ratio was $1.2 \pm 0.3$ (Fig. 4B). A positive and significant linear correlation was found between R and GPP $(r=0.8$; $p<0.0001 ; n=21)$, with a slope $(1 \pm 0.2$, slope \pm standard error) not significantly different from 1 , corresponding to a well-balanced planktonic

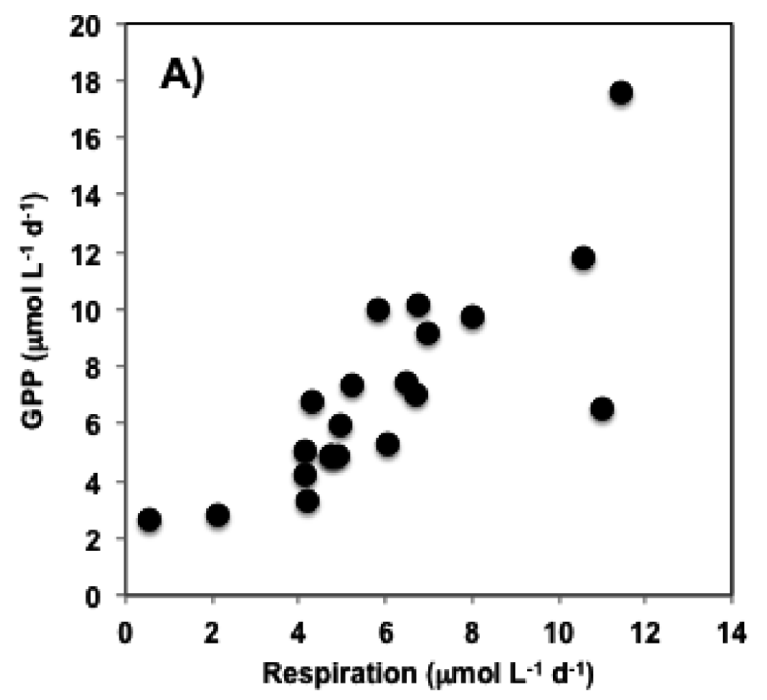

metabolism on the surface of the reservoir during the bloom (Fig. 5A).

The efficiency of the conversion of GPP into NEP is frequently estimated as the NEP:GPP ratio expressed as percentages (see Odum, 1985). We computed this efficiency for each day with a positive NEP throughout the study period (Fig. 4C), and obtained a mean of $25.6 \pm 19 \%$ (minimum $2.5 \%$, maximum $78.8 \%$ ). Interest-

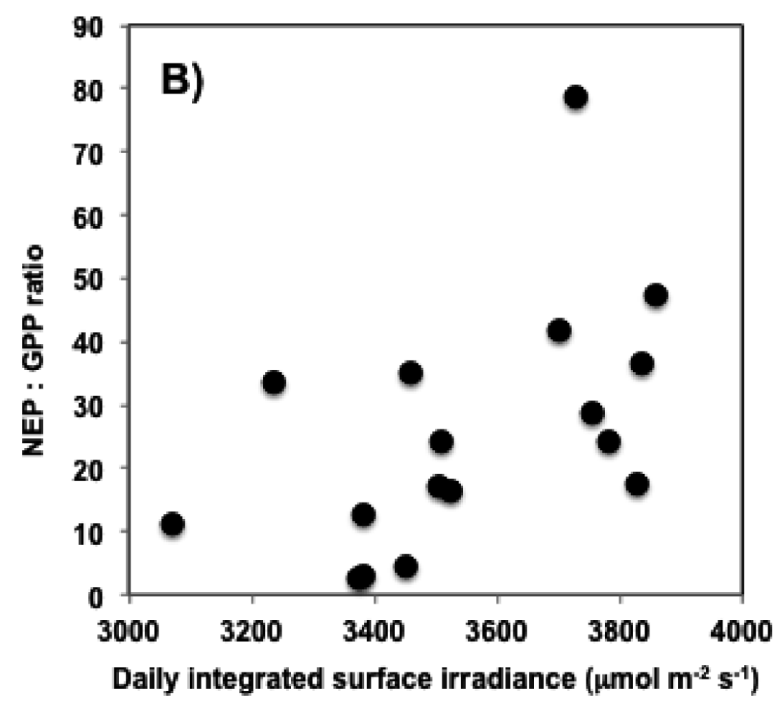

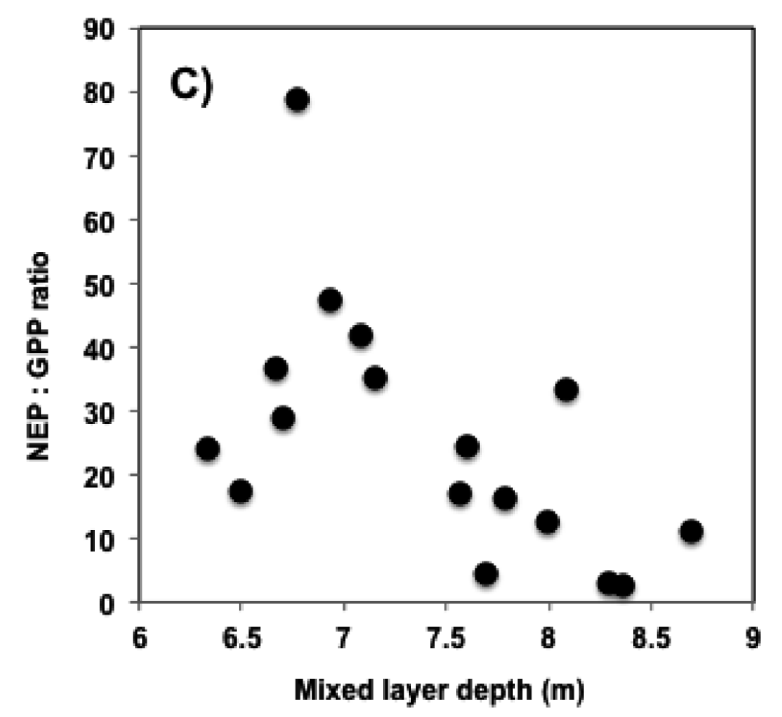

Figure 5. The relationships between A) R and GPP, B) PAR and NEP:GPP, and C) mixed-layer depth and NEP:GPP, in the nearsurface waters of El Gergal reservoir. Correlation parameters are given in the text. Relación entre A) $R$ y GPP, B) PAR y NEP:GPP, y C) profundidad de la capa de mezcla y NEP:GPP, en las aguas superficiales del embalse de El Gergal. Parámetros de la correlaciones en el texto. 
ingly, this efficiency showed a positive and significant linear correlation $(r=0.51 ; p<0.005$; $n=17$ ) with the daily integral PAR field arriving at the reservoir surface (Fig. 5B) and a negative linear correlation $(r=-0.57 ; p<0.005 ; n=17)$ with the mixed-layer depth (Fig. 5C).

The chlorophyll $a$-specific production rate (GPP:Chl $a$ ratio) ranged between $0.09 \mu \mathrm{mol} \mathrm{O}$ $\mu \mathrm{g} \mathrm{Chl} a^{-1} \mathrm{~d}^{-1}$ and $0.62 \mu \mathrm{mol} \mathrm{O} 2 \mu \mathrm{g} \mathrm{Chl} a^{-1} \mathrm{~d}^{-1}$, with an overall mean of $0.3 \pm 0.1 \mu \mathrm{mol} \mathrm{O}_{2} \mu \mathrm{g} \mathrm{Chl}$ $a^{-1} \mathrm{~d}^{-1}$. In agreement with this, the chlorophyll $a$-specific respiration rate ( $\mathrm{R}: \mathrm{Chl} a$ ratio) exhibited an overall mean of $0.2 \pm 0.1 \mu \mathrm{mol} \mathrm{O} \mathrm{O}_{2} \mu \mathrm{g} \mathrm{Chl}$ $a^{-1} \mathrm{~d}^{-1}$, with a minimum of $0.02 \mu \mathrm{mol} \mathrm{O}_{2} \mu \mathrm{g}$ Chl $a^{-1} \mathrm{~d}^{-1}$ and a maximum of $0.49 \mu \mathrm{mol} \mathrm{O} 2 \mu \mathrm{g}$ Chl $a^{-1} \mathrm{~d}^{-1}$. A positive and highly significant linear correlation was found between $\mathrm{R}: \mathrm{Chl} a$ and GPP:Chl $a(r=0.84 ; p<0.0001 ; n=21)$, with a slope $(1.1 \pm 0.3$, slope \pm standard error $)$ not significantly different from 1 .

\section{DISCUSSION}

Summer blooms of large filamentous and diazotrophic cyanobacteria are characteristic of many productive, warm monomictic lakes and reservoirs in the Mediterranean region, where they constitute stable episodes in phytoplankton succession. In the El Gergal reservoir, these summer blooms consisted mainly of Aphanizomenon flos-aquae and Anabaena planctonica. These positively buoyant phytoplankters accumulate in the surface layer of the reservoir during calm weather, low turbulent mixing periods, where they form stable and dense scums and patches (Moreno-Ostos et al., 2009a, 2009b, 2012). Surface blooms can intercept a large amount of the incident light and inorganic carbon fluxes from the air, giving the buoyant cyanobacteria competitive advantages over other phytoplankton groups (Paerl \& Ustach, 1982; Ibelings \& Maberly, 1998). In addition, their position in the water column favours nitrogen fixation through the photosynthetic process (Walsby et al., 1997), which also promotes cyanobacterial dominance in the typically nutrient-depleted, late-summer epilimnion.
Previous studies have shown that photosynthesis is generally high during summer surface blooms, with a large contribution from filamentous cyanobacteria to the total primary production (Ploug, 2008; Ploug et al., 2010), and oxygen concentration in the surface layers is frequently supersaturated during cyanobacterial blooms (Ibelings \& Mur, 1992; Ibelings \& de Winder, 1994). However, in the surface layers of the El Gergal reservoir, the differences between GPP and $\mathrm{R}$ were rather small. R and GPP were closely correlated with a slope not significantly different than 1 , and the mean GPP:R ratio was low $(1.2 \pm 0.3)$, revealing the predominance of a well-balanced planktonic metabolism during the bloom. In addition, the mean efficiency in the conversion of GPP into NEP (the NEP:GPP ratio) was generally low, with an overall mean of $25 \%$. Cremona et al. (2014) and Noges et al. (2011) described similar GPP:R ratios and chlorophyll-specific production rates under light saturation in a large, eutrophic, cyanobacteriadominated lake. They concluded that both the high turbidity of the lake and the dominance of slow-growing cyanobacteria, which have a low photosynthetic efficiency compared with other phytoplankton groups, could explain these metabolic features (Laas et al., 2012). Similarly, Staehr et al. (2010b) found GPP:R ratios close to 1.0 and positive correlations of GPP and R in stratified lakes, which were explained by the relatively rapid and efficient respiration by microbial loops and zooplankton in the newly produced organic matter (Lass et al., 2012). In this context, Hanson et al. (2003) noted that a good proportionality of GPP and R suggests that autochthonous carbon provides most of the substrate for pelagic respiration.

All the above explanatory factors fully applied to El Gergal during the summer blooms, when the Secchi depth is generally less than $1 \mathrm{~m}$, large slow-growing cyanobacteria constitute the main phytoplankton group, and allochthonous carbon input is neglected as external tributaries to the reservoir are typically eliminated by severe droughts (Cruz-Pizarro et al., 2005).

It is well known that large nitrogen-fixing cyanobacteria blooms enhance the microbial loop 
and prevent the development of large zooplankton grazers (Gliwicz, 1990; Gliwicz \& Lampert, 1990; Moreno-Ostos et al., 2007b) within the planktonic community. In these cases, a close autotrophic-microheterotrophic cooperative association exists within the pelagic plankton, which can lead to efficient organic matter recycling and nutrient uptake in the surface layers. Previous studies (Glibert \& Bronk, 1994; Larsson et al., 2001; Mulholland \& Capone, 2001; Rolff et al., 2007; Ploug et al., 2010.) have shown that filamentous diazotrophic cyanobacteria frequently fix surplus dinitrogen, which is leaked to the associated microheterotrophic community, increasing microbial respiration and consequently enhancing the dissolved inorganic carbon and nutrients available for photoautotrophs (Forsskal et al., 1982; Sellner, 1997; Ploug, 2008). Similarly, the equilibrated planktonic metabolism found in the surface waters of $\mathrm{El}$ Gergal suggests the existence of tight mutualistic feed-back mechanisms between the large nitrogen-fixing cyanobacteria and associated microheterotrophic organisms, which could favour the stable persistence of the cyanobacterial bloom at the surface of the reservoir. Our results also suggest that this stable planktonic assemblage would be finally overcome by physical factors, such as the progressive deepening of the mixed layer and light limitation. Thus, we found a direct relationship between the daily integrated incident light and the NEP:GPP ratio, while the NEP:GPP ratio was negatively correlated with the mixed-layer depth.

In a previous paper on the same reservoir, Moreno-Ostos et al. (2009b) used highfrequency data collected by the AWQMS to investigate the negative influence of wind-induced turbulent mixing on the persistence of positively buoyant cyanobacterial scums. They found that frequent wind-mixing events in El Gergal could overcome the flotation capacity of Aphanizomenon flos-aquae, thus homogenising their vertical distribution throughout the increased mixed layer and transporting the cyanobacteria beyond the euphotic layer, where they became light-limited. Following Huisman et al. (2004), these results may be useful applications in water management for improving predictions of the mixing intensity required to avoid or overcome harmful cyanobacterial surface blooms. As the mixed-layer depth in multilevel withdrawal water supply reservoirs is strongly dependent on the withdrawal depth (Moreno-Ostos et al., 2008b), reservoir managers could prevent the development of cyanobacterial blooms by simply extracting water from the hypolimnion during summer, a hydraulic management strategy that would promote deepening of the mixed layer towards light-limited depths and result in the decay of cyanobacterial production efficiency. Recent selective withdrawal experiments to control harmful cyanobacterial blooms (i.e., Lehman et al., 2009; McDonald \& Lehman, 2013) demonstrated that hypolimnetic withdrawal significantly destabilized the water column, favouring the near elimination of Aphanizomenon and its replacement by diatoms. The same authors concluded that this hydraulically induced phytoplankton community transformation constitutes a successful and reproducible management strategy for addressing summer cyanobacterial blooms in reservoirs.

For this study, we combined a moored automatic high frequency monitoring system with the diel free-water oxygen technique to investigate daily changes in near-surface reservoir planktonic metabolism during a cyanobacterial bloom. This ecosystem approach has provided estimations on the magnitude and variability of metabolic rates over realistic time scales, significantly improving our understanding of the functional characteristics of cyanobacterial blooms in Mediterranean reservoirs.

\section{ACKNOWLEDGEMENTS}

This study was funded by project CGL200504070/HID, Spatial and temporal patterns in the hydrodynamics-plankton coupling: impact of exogenous perturbations in a mesotrophic reservoir in Southern Iberian Peninsula (El Gergal, Seville) and was developed within the framework of the European EU-COST ES1201 Networking Lake Observatories in Europe (NetLake). Logis- 
tical support was provided by the Metropolitan Water Supply Company of Seville (EMASESA). We greatly appreciate the constructive and helpful comments of two anonymous referees.

\section{REFERENCES}

BACKER, L. C. 2002. Cyanobacterial harmful algal blooms (CyanoHABs): Developing a public health response. Lake and Reservoir Management, 18: 20-31.

BENDER, M., K. GRANDE, K. JOHNSON, J. MARRA, P. J. LeB. WILLIAMS, J. SIEBURTH, M. PILSON, C. LANGDON, G. HITCHCOCK, J. ORCHARDO, C. HUNT \& P. DONAGHAY. 1987. A comparison of four methods for determining planktonic community production. Limnology and Oceanography, 32: 1085-1098.

CHEN, C. C., J. E. PETERSEN \& W. M. KEMP. 2000. Nutrient-uptake in experimental estuarine ecosystems: scaling and partitioning rates. Marine Ecology Progress Series, 200: 103-116.

COLE, J. J. \& N. F. CARACO. 1998. Atmospheric exchange of carbon dioxide in a low-wind oligotrophic lake measured by the addition of SF6. Limnology and Oceanography, 43: 647-656.

COLE, J. J., M. L. PACE, S. R. CARPENTER \& J. F. KITCHELL. 2000. Persistence of net heterotrophy in lakes during nutrient addition and food web manipulations. Limnology and Oceanography, 45: 1718-1730.

CREMONA, F., T. KOIV, V. KISAND, A. LAAS, P. ZINGEL, H. AGASILD, T. FELDMANN, A. JÄRVALT, P. NOGES \& T. NOGES. 2014. From bacteria to piscivorous fish: Estimates of wholelake and component-specific metabolism with an ecosystem approach. PlosOne, 9: 1-12.

CRUZ-PIZARRO, L., A. BASANTA, C. ESCOT, E. MORENO-OSTOS \& D. G. GEORGE. 2005. Temporal and spatial variations in the quality of water in El Gergal reservoir, Seville, Spain. Freshwater Forum, 23: 62-77.

DEL GIORGIO, P. \& C.M. DUARTE. 2002. Respiration in the open ocean. Nature, 420: 379-384.

DUARTE, C. M. \& Y. T. PRAIRIE. 2005. Prevalence of heterotrophy and atmospheric $\mathrm{CO}_{2}$ emissions from aquatic ecosystems. Ecosystems, 8: 862-870.

ESCOT, C., M. PIQUERAS, M. VÁZQUEZ, \& A. BASANTA. 2009. Sistema de información automática de la calidad del agua de los embalses de abastecimiento a Sevilla y su área metropolitana. Tecnoambiente, 194: 15-18.

FORSSKAL, M., A. LAAKKONEN, J. M. LEPPÄNEN, A. NIEMI, A. SUNDBERG \& G. TAMELANDER. 1982. Seasonal cycle of production and sedimentation of organic matter at the entrance of the Gulf of Finland. Netherland Journal of Sea Research, 16: 290-299.

GERHART, D. Z. \& G. E. LIKENS. 1975. Enrichment experiments for determining nutrient limitation-4 methods compared. Limnology and Oceanography, 20: 649-653.

GLIBERT, P. M. \& D. A. BRONK. 1994. Release of dissolved organic nitrogen by marine diazotrophic cyanobacteria, Trichodesmium spp. Applied Environmental Microbiology, 60: 3996-4000.

GLIWICZ, Z. M. 1990. Why do cladocerans fail to control algal blooms?. Hydrobiologia, 200/201: 83-98.

GLIWICZ,Z. M. \& W. LAMPERT. 1990. Food thresholds in Daphnia species in the absence and presence of blue-green filaments. Ecology, 71: 691-702.

HANSON, P. C., D. L. BADE \& S. R. CARPENTER. 2003. Lake metabolism: Relationships with dissolved organic carbon and phosphorous. Limnology and Oceanography, 48: 1112-1119.

HANSON, P. C., S. R. CARPENTER, D. E. ARMSTRONG \& E. H. STANLEY. 2006. Lake dissolved inorganic carbon and dissolved oxygen: Changing drivers from days to decades. Ecological Monographs, 76: 343-363.

HILLEBRANT, H., C. D. DÜRSELEN, D. KIRSCHTEL, U. POLLINGHER \& T. ZOHARY. 1999. Biovolume calculation for pelagic and benthic microalgae. Journal of Phycology, 35: 403-424.

HOYER, A. B., E. MORENO-OSTOS, J. VIDAL, J. M. BLANCO, R. L. PALOMINO-TORRES, A. BASANTA, C. ESCOT \& F. J. RUEDA. 2009. The influence of external perturbations on the fucntional composition of phytoplankton in a Mediterranean reservoir. Hydrobiologia, 627:1-17.

HUISMAN, J., J. SHARPLES, J. M. STROOM, P. M. VISSER, W. E. A. KARDINAAL, J. M. H. VERSPAGEN \& B. SOMEIJER. 2004. Changes in turbulent mixing shift competition for light between phytoplankton species. Ecology, 85: 2960 2970.

IBELINGS, B. W. \& L. R. MUR. 1992. Microprofiles of photosynthesis and oxygen concentration in $\mathrm{Mi}$ - 
crocystis sp. Scums. FEMS Microbiology Ecology, 86: 195-203.

IBELINGS, B. W. \& B. de WINDER. 1994. The effect of irradiance, temperature and desiccation on cyanobacterial photosynthesis: A possible explanation for diurnal variation in surface water blooms. In: Microbial mats. L.S. Stal \& P. Caumette (Eds.): 311-318. Springer Verlag.

IBELINGS, B. W. \& S. C. MABERLY. 1998. Photoinhibition and the availability of inorganic carbon restrict photosynthesis by surface blooms of cyanobacteria. Limnology and Oceanography, 43: 408-419.

JÄHNE, B., O. MÜNNICH, R. BÖSINGER, A. DUTZI, W. HUBER \& P. LIBNER. 1987. On the parameters influencing air-water gas exchange. Journal of Geophysical Research, 92: 1937-1949.

LAAS, A., P. NOGES, T. KOIV \& T. NOGES. 2012. High-frequency metabolism study in a large and shallow temperate lake reveals seasonal switching between net autotrophy and net heterotrophy. $\mathrm{Hy}$ drobiologia, 694: 57-74.

LARSSON, U., S. HAJDU, J. WALVE \& R. ELMGREN. 2001. Baltic Sea nitrogen fixation estimated from the summer increase in the upper mixed layer total nitrogen. Limnology and Oceanography, 46: 811-820.

LAUSTER, G. H., P. C. HANSON \& T. K. KRATZ. 2006. Gross primary production and respiration differences among littoral and pelagic habitats in northern Wisconsin lakes. Canadian Journal of Fisheries and Aquatic Sciences, 63: 1130-1141.

LEHMAN, E. M., K. E. McDONALD \& J. T. LEHMAN. 2009. Whole lake selective withdrawal experiment to control harmful cyanobacteria in an urban impoundment. Water Research, 43: 11871198.

McDONALD, K. E. \& J. T. LEHMAN. 2013. Dynamics of Aphanizomenon and Microcystis (cyanobacteria) during experimental manipulation of an urban impoundment. Lake and Reservoir Management, 29: 103-115.

MORENO-OSTOS, E., J. A. ELLIOTT, L. CRUZ-PIZARRO, C. ESCOT, A. BASANTA \& D. G. GEORGE. 2007a. Using a numerical model (PROTECH) to examine the impact of water transfers on phytoplankton dynamics in a Mediterranean reservoir. Limnetica, 26: 1-11.

MORENO-OSTOS, E., S. L. RODRIGUES DA SILVA, I. DE VICENTE \& L. CRUZ-PIZARRO. 2007b. Interannual and between-site variability in the occurrence of clear water phases in two shallow Mediterranean lakes. Aquatic Ecology, 41: 285-297.

MORENO-OSTOS, E., L. CRUZ-PIZARRO, A. BASANTA \& D. G. GEORGE. 2008a. The spatial distribution of different phytoplankton functional groups in a Mediterranean reservoir. Aquatic Ecology, 42: 115-128.

MORENO-OSTOS, E., R. MARCÉ, J. ORDÓÑEZ, J. DOLZ AND J. ARMENGOL. 2008b. Hydraulic management drives heat budgets and temperature trends in a Mediterranean reservoir. International Review of Hydrobiology, 93: 131-147.

MORENO-OSTOS, E., L. CRUZ-PIZARRO, A. BASANTA \& D. G. GEORGE. 2009a. Spatial heterogeneity of cyanobacteria and diatoms in a thermally stratified canyon-shaped reservoir. International Review of Hydrobiology, 94(3): 245-257.

MORENO-OSTOS, E., L. CRUZ-PIZARRO, A. BASANTA \& D. G. GEORGE. 2009b. The influence of wind-induced mixing on the vertical distribution of buoyant and sinking phytoplankton species. Aquatic Ecology, 43: 271-284.

MORENO-OSTOS, E., J. M. BLANCO, R. L. PALOMINO-TORRES, J. LUCENA, V. RODRÍGUEZ, D. G. GEORGE, C. ESCOT \& J. RODRÍGUEZ. 2012. The Gulf Stream position influences the functional composition of phytoplankton in $\mathrm{El}$ Gergal reservoir (Spain). Limnetica, 31: 251-260.

MULHOLLAND, M. R. \& D. G. CAPONE. 2001. Stoichiometry of nitrogen utilization in cultured populations of Trichodesmium IMS101: Implications for growth. Limnology and Oceanography, 46: 436-443.

NOGES, T., H. ARST, A. LASS, T. KAUER, P. NOGES \& K. TOMING. 2011. Reconstructed longterm time series of phytoplankton primary production of a large shallow temperate lake: the basis to assess the carbon balance and its climate sensitivity. Hydrobiologia, 667: 205-222.

ODUM, H. T. 1956. Primary production in flowing waters. Limnology and Oceanography, 1: 102-117.

ODUM, H. T. 1957. Trophic structure and productivity of Silver Springs, Florida. Ecological Monographs, 27: 55-112.

ODUM, E. P. 1985. Fundamentos de Ecología. Ed. Interamericana. México.

ODUM, H. T. \& E. P. ODUM. 1955. Trophic structure and productivity of a windward coral reef community on Eniwetok Atoll. Ecological Monographs, 25: 291-320. 
ODUM, H. T. \& C. M. HOSKIN. 1958. Comparative studies of the metabolism of Texas bays. Publications of the Institute of Marine Science University of Texas, 5: 15-46.

PAERL, H. W. \& J. USTACH. 1982. Blue-green algal scums: an explanation for their occurrence during freshwater blooms. Limnology and Oceanography, 27: 212-217.

PAERL, H. W. \& T. G. OTTEN. 2013. Harmful cyanobacteria blooms: Causes, consequences, and control. Microbial Ecology, 65: 995-1010.

PETERSEN, J. E., C. C. CHEN \& W. M. KEMP. 1997. Scaling aquatic primary productivity: Experiments under nutrient- and light-limited conditions. Ecology, 78: 2326-2338.

PETERSEN, J. E., J. C. CORNWELL \& W. M. KEMP. 1999. Implicit scaling in the design of experimental aquatic ecosystems. Oikos, 85: 3-18.

PLOUG, H. 2008. Cyanobacterial surface blooms formed by Aphanizomenon sp. and Nodularia spumigena in the Baltic Sea: Small-scale fluxes, $\mathrm{pH}$, and oxygen microenvironments. Limnology and Oceanography, 53: 914-921.

PLOUG, H., N. MUSAT, B. ADAM, C. L. MORARU, G. LAVIK, T. VAGNER, B. BERGMAN \& M. M. KUYPERS. 2010. Carbon and nitrogen fluxes associated with the cyanobacterium Aphanizomenon sp. in the Baltic Sea. The ISME Journal, 4: 1215-1223.

ROLFF, C., L. ALMESJÖ \& R. ELMGREN. 2007. Nitrogen fixation and abundance of the diazotrophic cyanobacterium Aphanizomenon sp. in the Baltic Proper. Marine Ecology Progress Series, 332: 107-118.

ROUEN, M., D. G. GEORGE, J. KELLY, M. LEE \& E. MORENO-OSTOS. 2005. High-resolution automatic water quality monitoring systems applied to catchment and reservoir monitoring. Freshwater Forum, 23: 20-37.

SCHINDLER, D. E., S. R. CARPENTER, J. J. CO-
LE, J. F. KITCHELL \& M. L. PACE. 1997. Influence of food web structure on carbon exchange between lakes and the atmosphere. Science, 277: 248-251.

SELLNER, K. G. 1997. Physiology, ecology, and toxic properties of marine cyanobacterial blooms. Limnology and Oceanography, 42: 1089-1104.

STAEHR, P. A. \& K. SAND-JENSEN. 2007. Temporal dynamics and regulation of lake metabolism. Limnology and Oceanography, 52: 108-120.

STAEHR, P. A., D. BADE, M. C. VAN de BORGET, G. R. KOCH, C. WILLIAMSON, P. HANSON, J. J. COLE \& T. KRATZ. 2010a. Lake metabolism and the diel oxygen technique: state of the science. Limnology and Oceanography: Methods, 8: 628644.

STAEHER, P. A., K. SAND-JENSEN, A. L. RAUN, B. NIELSSON \& J. KIDMOSE. 2010b. Drivers of metabolism and net heterotrophy in contrasting lakes. Limnology and Oceanography, 55: 817830.

STAEHR, P. A., L. BAASTRUP-SPOHR, K. SANDJENSEN \& C. STEDMON. 2012. Lake metabolism scales with lake morphometry and catchment conditions. Aquatic Sciences, 74: 155-169.

UTERMÖHL, H. 1958. Zur Vervollkommung der Quantitativen Phytoplankton-Methodik. Mitteilungen Internationale Vereinigung für Theoretische und Angewandte Limnologie, 9: 1-39.

WALSBY, A. E. P. K. HAYES, R. BOJE \& L. STAL. 1997. The selective advantage of buoyancy provided by gas vesicles for planktonic cyanobacteria in the Baltic Sea. New Phytologist, 136: 407-417.

WILLIAMSON, C. E., W. DODDS, T. K. KRATZ \& M. A. PALMER. 2008. Lakes and streams as sentinels of environmental change in terrestrial and atmospheric processes. Frontiers in Ecology and the Environment, 6: 247-254.

ZAR, J. H. 1999. Biostatistical Analysis. Prentice Hall. New Jersey. USA. 